The
Journal of
Social
Science

DOI: $10.30520 /$ tjsosci.777912

\title{
THE DIVINE UNITY IN AND BEYOND NATURE: A COMPARATIVE STUDY IN WALT WHITMAN'S AND JALAL AD-DIN MUHAMMAD RUMI'S ECSTATIC POEMS
}

Melih KÖKCÜ${ }^{1}$

\begin{abstract}
As of today, the teachings of Rumi, Ibn al-Arabi and other Sufi mystics are enjoying a considerable revival in the United States. Especially ecstatic poems of Jalal ad-Din Muhammad Rumi have sold hundreds of thousands of copies recently, making him a best-selling poet not only in the United States but also in other many countries. The roots of American fascination for Sufism, however, reach as deep as the nineteenth century when American transcendentalism appeared as an expression within Romanticism as a literary movement. This paper aims to compare the concept of the Divine Unity in both seemingly unrelated philosophical movements in terms of how the ecstatic poems of Walt Whitman and Jalal ad-Din Muhammad Rumi transcend physical existence in nature to see the truth of the universe, which means, for all of them, the unity with God. Some studies, albeit clear differences between two traditions, show evidence to commentate that their mystical and transcendental tenets share a basic understanding of human desire leading to the Divine Unity. Two religious and philosophical movements argue about omnipresence and omnipotence of God and in this point nature plays a crucial role as God's perfect manifestation. The ascetic poems of Rumi, the thirteenth-century Sufi Muslim philosopher born in today's Afghanistan, and the transcendental poems of Whitman, the nineteenthcentury Christian transcendentalist from New York, are bedecked with similar natural elements to see what lays beyond form in compossible nature.
\end{abstract}

Keywords: Sufism, American Transcendentalism, Poetry, Jalal ad-Din Muhammad Rumi, Walt Whitman

\section{Introduction}

Sufism as proclaimed philosophical movement alongside religious belief is interested in the ethereal spirituality of the devotee and motifs leading the murid or disciple obeying his/her sheikh or master to the last phase of his/her inner experience as well as spiritual upliftment of the individual in American transcendentalism. In this point, both traditions share a single intent; that is, offering guidance to the individual through his/her experience in this journey towards the Divine Unity that is, as a term, related to Wahdat al-Wujud, a doctrine that was created by Ibn al-Arabi, or it is supposed that he had established the term. This doctrine is defined by Glassé (2001) as the doctrine of the unity of being, associated with Ibn al-Arabi and his school.

\footnotetext{
${ }^{1}$ Holder of a master's degree in Religious Studies (University of Erfurt) and graduate student in Radio, Television and Cinema at Ibn Haldun University, melihkokcu@ hotmail.com, ORCID: 0000-00031984-1718
} 


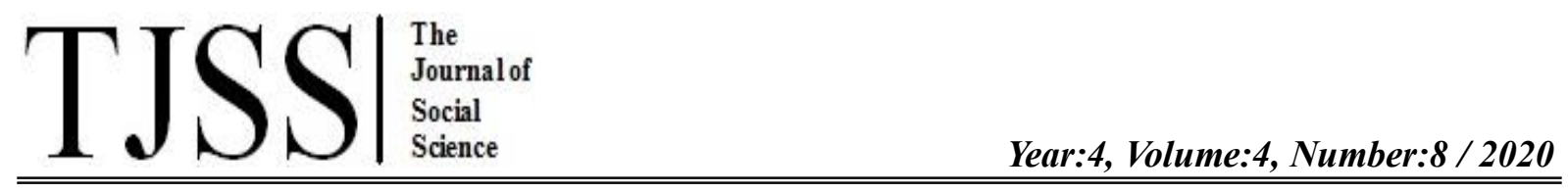

Also, the term is simply related to "oneness of being" or "unity of existence" (Chittick, 2004: 727). Transcendentalism in the United States is mostly studied as an expression of American Romanticism when considered as a literary movement. Although Romanticism is regarded as a secular literary movement freed from organizational belief systems, American transcendentalism articulates its own religious tenets in a transcendental being and unifying force which might be called God, rather than in God's trinity. This unifying force is mentioned as the over-soul by the leading spokesman of this religious and literary tradition, Ralph Waldo Emerson. Whitman, American transcendentalist poet, also talks about an omnipresent existence in his poems. God is a permeating substance for the Transcendentalists and they are fascinated with nature as a unifying inspiration. American transcendentalism and Sufism alike consider nature as a divine manifestation of God's omnipresence and almightiness in the universe. A gurgling waterfall, a sunset, or a gliding bird may be, for either Sufis or Transcendentalists, a muse leading them to discovery of God within the beauty of nature. Sufis are concerned with nature as in American transcendentalism, but in a different manner. For the Sufis, nature is a reflection of God's omnipresence and they can be intoxicated by these attributes of God in nature by commemorating the unity with God, which means the Divine Unity, whereas the Transcendentalists may consider God as a whole substance of natural components. For example, a serene view of the setting sun upon a rough sea with the sound of seagulls may evoke the concept of God for the Transcendentalists, but this view signifies only an attribute of God for the Sufis. However, nature has the same importance in both Sufism and American transcendentalism to delineate the Divine Unity in their ecstatic poems.

\section{Nature in Sufism and American Transcendentalism}

Nature is a divine manifestation according to Sufism and American transcendentalism. It is depicted as rather joyful and stimulating in their poems as well as mysterious. But above all, nature became an inspiration for poets in both traditions to transcend beyond ephemeral existence and enhance their state of mind into the level of the Divine Unity. Transcendentalists believe that nature is pure substance for the individual to reach his/her goal of being in communication with God and Sufis accordingly remark the unity with God in nature, where Quranic revelation reveals in Islam. Manzari writes about the sanctity of nature in transcendentalist philosophy that "nature is the place where God can be found; it is a source of nourishment, of beauty and inspiration... It is where man can regenerate himself, without the help of traditional, institutional religion" (Manzari, 2012: 63). Transcendentalists notably reject religious intermediaries and institutions that are supposed to ensure spiritual inner peace. Nature, which embodies a wide range of formation from microorganisms to miscellaneous constituents, therefore, plays a fundamental role as a constant reminder of the oneness of the universe, in which everything comes together, or fraternizes, within itself under the roof of God. In her article, "Walt Whitman's "Sea Drift" Cluster: The Encounter of Sufi and American Selves at Paumanok" Elena Furlanetto (2017) argues that nature is a spiritual (sacred) place for both traditions and emphasizes that encounter of Whitman and Hafiz with mockingbird and nightingale happens in nature and this incidence is highly important for discernment of the Divine.

As Emerson describes nature in "The Poet", it has its own inherently divine dynamics within "a certain self-regulated motion or change" (Emerson, 1968: 22). He considers nature also as a divine inspiration for the poet, exactly like a Sufi who is, in contemplation, inspired 
by nature. Obvious fascination of the nineteenth-century American transcendentalist poets for Sufism enables today's readerships to read their spiritual poems from both Transcendentalist and Sufi perspectives. Hence, American transcendentalism considerably incorporates such essential esoteric Sufi themes as love, complaisance and divinity of nature. In his poem, "Saadi" in Poems he talks of "the poet, who dwells alone" (Emerson, 1968: 129) as a wise personality, who contemplates the Divine penetrating in God's attributes. He continues in "Saadi" in Poems as below:

\author{
Sad eyed Fakirs swiftly say \\ Endless dirges to decay; \\ Never in the blaze of the light \\ Lose the shudder of midnight \\ And at overflowing moon, \\ $\cdots$ \\ Hear the far Avenger's feet; \\ And shake before those awful powers \\ Who in their pride forgive not ours.
}

(Emerson, 1968: 131)

"Sad eyed Fakirs" (Emerson, 1968: 131) pray and seek mercy because they are all dismayed by vengeance of God, whose name is not taught and enunciated by devotees. "Those awful powers" (Emerson, 1968: 131) render an authority which is possibly endangered by religious conceited leaders. However, Sa'adi is represented, opposed to sad eyed Fakirs, as a delighted devotee of God, who seeks Him in nature. He is a suffering hero, which "sunshine in his heart transferred" (Emerson, 1968: 132) and "lighted each transparent word" (Emerson, 1968: 132). He loves everything in the universe and this affection leads him to attain the divine knowledge by heart (qalb). Likewise, Rumi uses natural elements, which provide a romantic imaginary, to emphasize nature's greatness and superiority for a spiritual realization of the Divine Unity in his poems.

\footnotetext{
The hills and dales, rivers, oceans and lands, all, are like the teaching board in the classroom, for the people with vision.
}

(Rumi in Bala Ruma, 2012: 80)

According to the lines above, the human being should take a lesson from nature, that is, to realize the Divine Unity. These lines of Rumi are reminiscent of the idyllic rural setting Emerson (1968) creates a broad-visioned Sufi in "Saadi", where Sa'adi dwells in nature, and his vast Persian audiences visit him in his dwelling to learn from him. 


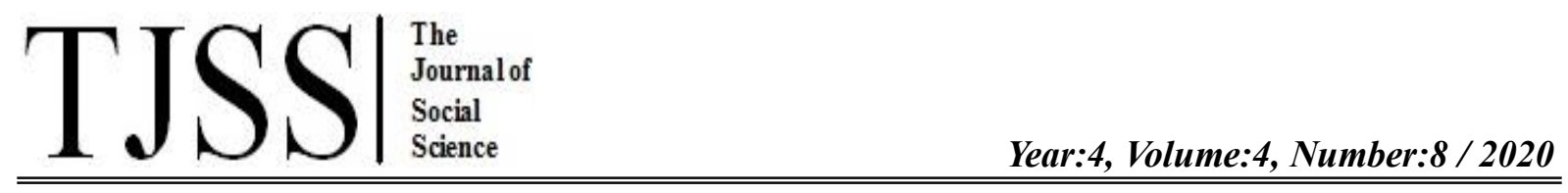

Nature is a sacred phenomenon for both traditions that contains divine ideas. In his book, The Mystics of Islam Reynold A. Nicholson (1914) explains the concept of God in nature from the Sufi perspective.

God is the One Real Being which underlies all phenomena. This principle is carried to its extreme consequences... If nothing except God exists, then the whole universe, including man, is essentially one with God, whether it is regarded as an emancipation which proceeds from Him, without impairing His unity, like sunbeams from the sun, or whether it is conceived as a mirror in which the divine attributes are reflected (Nicholson, 1914: 80).

God is "the eternal Beauty" (Nicholson, 1914: 80) for the Sufis that is hidden in nature. The physical existence reflects God's eternal divine unity that "lies in the nature of beauty to desire love" (Nicholson, 1914: 80). Sufism argues that only God has its continuity and everything in the manifested universe is transient due to its inevitable mortality. Sufis correspondingly use both material and immaterial continuity in their philosophy to phrase the essential unity of substances in the Divine by emphasizing that God is a superior power to the entire universe. Ibn al-Arabi writes about oneness and inimitability of God in Risalat al-Ahadiyah that "none knows Him but He himself. He knows Himself by Himself. Other-than-He cannot grasp Him. His impenetrable veil is His own Oneness. Other-than-He has no existence and so cannot bring itself to naught" (Ibn al-Arabi in Burckhardt, 2008: 17-18). According to Ibn al-Arabi's philosophy God is immanent and nature is His manifestation that exclusively belongs to Him. Similarly, Transcendentalist poets assume that God and His attributes act in nature concertedly. Emerson has a similar explanation about the oneness of the eternal one, or the purported soul in "The Over-Soul" (Emerson, 1968: 269) and all the divine attributes in nature. These two important spiritual movements are fundamentally based on the idea that there is a great harmony in the creation of God and He is visible and comprehensible among His manifestation. Transcendentalist and Sufi poets are, furthermore, keen on juggling with nature in microcosmmacrocosm relation to explain nature's divine harmony. It is a vision of cosmos, in which the part of it (microcosm) is related with the whole (macrocosm). Namely, nature is a supplemental picture of these microcosms; which means that each phenomenon or natural event symbolizes a microcosm, but they present a whole when they are congregated. Both Transcendentalists and Sufis benefit from microcosmic elements like blossoming roses and singing birds within nature, which they reflect a macrocosmic existence, to picture the Divine Unity.

More to this point, macrocosm contains binary oppositions beside similar components of nature. That is why harmony of contrasts is inspirational as well as scenic similarities for the Sufis since the Divine penetrates into all the animate and inanimate creation of God. As stated above, such contrarious behaviours of human beings as evil and good are simultaneously represented as interdependent and inherently cohesive in nature. For example, "dualistic concepts as those of active and passive, cause and effect, and finally good and evil" (Landau, 2008: 146) are significant for Ibn al-Arabi to explain the Divine. On a similar note, American transcendentalism speaks often of dualities and all contrasting dynamics in nature. Whitman as a conspicuous transcendentalist poet praises binary oppositions as flesh and soul, material and immaterial as well as Rumi and other Sufi philosophers. In short, nature as a harbor of oppositions and similarities is an important concept for both philosophical traditions because it is where God reveals Himself to the human being beyond form. 


\section{Divine Attributes in Ecstatic Poems of Whitman and Rumi}

American transcendentalism and Sufism emphasize the Divine Unity, which contains transnatural ideas beyond time and space, in terms of how manifestation (attributes) of God creates an ecstatic union with Him. Including the essence of a universal forcing power (God or the Over-Soul), there is a spiritualist perspective behind this union. Whitman and Rumi present an ethereal view of God in their poems laying stress on His omnipresence due to the numinous essence of God and His divine attributes. In this context, soul is the one that lasts forever and body is its ephemeral form in the world. Whitman presents his philosophy beyond time and space, which signifies that the Divine Unity is eternal, by claiming that "I have the best of time and space [and] there is limitless space and time" (Whitman, 1960: 79). Rumi also points out that soul reveals itself as a physical form in the world, and it belongs to nowhere but only to God. He writes in Mathnawi:

His form [of Sufi] is on Earth and his spirit is in "no-place", a "noplace" beyond the imagination of travelers (on the mystic way):

(Rumi, 1926: 87)

In Mathnawi he calls God as "the tree of knowledge in the sage" (Rumi, 1926: 412). He tells a story of "the seeker who was in the bondage of formalism" (Rumi, 1926: 412). Rumi pictures a seeker of the Truth, who is lost and in despair in Mathnawi.

\footnotetext{
"O Sheikh," he cried, "it is the time for mercy and pity;

I am in despair: now it is the time for kindness."

[The Sheikh asks the reason why he is desperately lost.]

[He answers that the emperor wants him to seek] a certain branching tree.

For there is a tree, unique in (all) the quarters (of the world):

its fruits is (of) the substance of the Water of Life
}

(Rumi, 1926: 412)

In this part of the story "a unique tree in all the quarters of the world" (Rumi, 1926: 412) refers to uniqueness and oneness of God and "its fruits of the substance of the Water of Life" (Rumi, 1926: 412) is related to divine knowledge leading the human being to eternity and the Divine Unity. The Sheikh further regards God as "the tree of knowledge in the sage" (Rumi, 1926: 412). He describes this tree as magnificent and boundless, and claims that "it [revelation or divine knowledge] is a Water of Life from the all-encompassing Seas (of God)" (Rumi, 1926: 412). In Mathnawi Rumi continues to portray the reality or God's unity beyond form on the same page. 


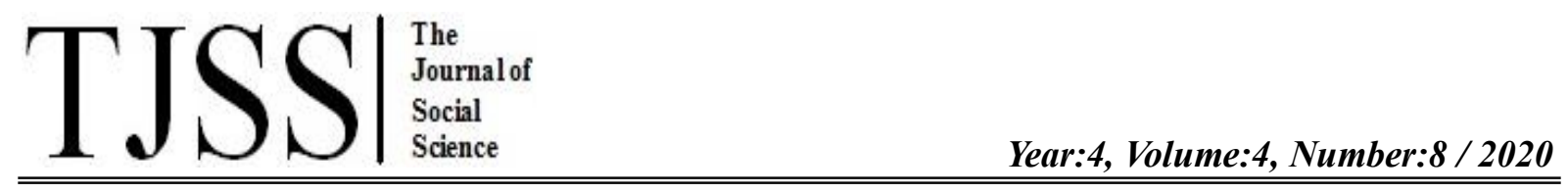

Thou hast gone after the form, thou hast gone astray: thou canst not find (it) because thou hast abandoned the reality.

Sometimes it is named 'tree', sometimes 'sun'; sometimes it is named 'sea', sometimes 'cloud'.

(It is) that one (thing) from which a hundred thousand effects: innumerable names befit (may be properly applied to) that one (thing)

(Rumi, 1926: 412)

Rumi means that all the attributes belong to God. Even though He is unique, His attributes are multiple and seen as form on the Earth. Rumi simultaneously emphasizes the multitude of God's attributes and also God's multiple manifestations guiding the devotee towards the Divine Unity.

Whitman enjoys the Divine Unity with an absolute optimism in his poems as well as Rumi. Michael Sowder writes in Whitman's Ecstatic Union that "Whitman's poetry everywhere seems to affirm the self and the world. It affirms that 'men and women and all that concerns them are unspeakable perfect miracles' and asserts that 'there is in fact no evil'" (Sowder, 2005: 44). According to Whitman's understanding of the Divine Unity there is philosophically no evil in God's creation and he believes in the absolute optimistic side of the union with God since his spiritual experience steers towards beatitude through dissolution or death. In Leaves of Grass he writes:

Do you see $\mathrm{O}$ my brothers and sisters?

It is not chaos or death... it is form and union and plan... it

is eternal life... it is happiness.

I depart as air... I shake my white locks at the runaway sun,

I effuse my flesh in eddies and drift it in lacy jags.

(Whitman, 1960: 85, 86)

Death is one of the most substantial metaphors in both philosophical traditions. It is one of the natural dynamics which belongs to God's precepts. Whilst physical death of human beings carries a meaning of worldly life's end and corporeal dissolution, it has a positive value for both spiritual traditions. Furlanetto (2017) also argues that death is dramatically metaphorical and she underlines 'death by drowning' in her article, "Walt Whitman's "Sea Drift" Cluster: The Encounter of Sufi and American Selves at Paumanok". She writes that "this metaphorical death is achieved through a symbolic drowning in the ocean, or the sea, which is a poignant metaphor for dissolution of the human body into the vastness of God" (Furlanetto, 2017: 104). In "As I Ebb'd with the Ocean of Life" Whitman (1942) depicts a positive picture of death in 
the ocean and it is explicitly shown as in a soothing atmosphere, as opposed to what is generally thought about death.

I mean tenderly by you and all,

I gather for myself and for this phantom looking down where we

lead, and following me and mine

Me and mine, loose windrows, little corpses,

Froth, snowy white, and bubbles,

(See from my dead lips the ooze exuding at last,

See, the prismatic colors glistening and rolling,)

(Whitman, 1942: 217)

"The prismatic colors" (Whitman, 1942: 217) in the poem signifies that death is idyllic and serene from the perspective of who experiences it. Surprisingly, the material oozing from the dead man's lips shows "prismatic colors [that] glisten and roll" (Whitman, 1942: 217). The speaker thus puzzles the reader by juxtaposing an image of unlikely beauty to the otherwise gruesome spectacle of a drowned corpse. Rumi has a positive view of death as well as Whitman. For example, he considers death as a gorgeous day when he reunites with his legendary beloved, Shams al-Tabrizi and God. Both of the poets do not regard death as the end of everything. They rather explain meaning of death as a process of rebirth. Rumi even says that a lover is keen on his/her quick death.

\begin{abstract}
A lover wants to die of his love
like a man with dropsy

who knows that water will kill him,

but he cannot deny his thirst.
\end{abstract}

A lover loves death. Spill your jug

in the river! Your shame and fear

are like felt layers covering coldness.

Throw them off, and rush naked

into the joy of death.

(Rumi, 2005: 126)

In "That Quick" in Rumi: The Book of Love Rumi (2005) portrays a lover who desires to be drowned in the ocean of love as soon as possible. In his poems he, just like Whitman, does not 
disdain the concept of death; on the contrary he praises death as an eternal phase of the human being. In his other poem, "Husam" in Rumi: The Book of Love he estimates death as "a way of passing away from the personal" (Rumi, 2005: 124) which results in plurality. For Rumi death creates a unique oneness of existence since it is philosophically cyclical. He utters that "we're given the gift of continuously dying and being resurrected" (Rumi, 2005: 125). Therefore, Rumi believes in continuity of the Divine, and that the contrast of birth and death is a gift to humanity. The natural cycle of birth and death is also central to "What Have I Ever Lost by Dying” (translated by Robert Bly), one of Rumi’s significant poems about death.

Rumi and Whitman assert that nature, all beings and even death are attributes of God and credentials of the Divine Unity. Nature and beings are divergent reflections of one unifying force which embodies everything. This unifying force is known as the Over-Soul in American transcendentalism while Sufism relates it with the concept of al-Haqq that refers to God as ultimate reality and truth. Whitman respects cosmic unity and propounds that God is everywhere as integrity of the whole in dynamics of human life. In Whitman's poem, "A Persian Lesson", a grey-bearded Sufi teaches his disciples that Allah is subsistent and He is all.

Allah is all, all, all - is immanent in every life and object,

May-be at many and many-a-more removes - yet Allah, Allah,

Allah is there.

(Whitman, 1891-92: 419)

God, or Allah, subsists in each element of His creation and small pieces (or atoms) of the unity coming from Him subsequently constitute the existence. Each element of the creation is, after all, driven to return towards its origin which is hidden in God. He writes in the same poem that "it is the central urge in every atom, to return its divine source and origin" (Whitman, 1891-92: 419). The spiritual impact of Rumi on Walt Whitman is evident in these lines as also Rumi writes of an inherent need of constitutive particles of God's divine creation to return to where they originally pertain. Rumi's philosophical creed is affiliated to the fact that God is all in human beings and nature.

The motion of every atom is towards its origin;

A man comes to be the thing on which he is bent.

By the attraction of fondness and yearning the soul and the heart

Assume the qualities of the Beloved and the soul of souls.

(Rumi, 1926: 254)

God's omnipresence is expressed in this stanza and He is perceived in every form and every reflection. The individual's desire to return to his/her origin and "to be the thing on which he is bent" (Whitman, 1891-92: 419) occur "by the attraction of fondness and yearning the soul 
and the heart" (Rumi, 1926: 254). Apart from returning to the origin of the human being, the Beloved that is a light to find the right path towards eternity of the origin appears in this stanza. To sum up, nature becomes a divine ambit, where the individual annihilates the self and achieves to realize the Divine Unity by death for both traditions.

\section{Conclusion}

This paper has carried out a comparative study of Sufism and American transcendentalism about the concept of the Divine Unity with focus on the philosophical impact of Rumi's esoteric poems upon Whitman's spiritual literary work. This article is situated in an interdisciplinary junction of American Literary Studies and Religious Philosophy. Namely, literary value of Sufism and American transcendentalism was taken into consideration besides their religious and philosophical value. Textual analysis and close readings of Whitman's and Rumi's poems ascertained Sufi impacts on American transcendentalism and excerpts of literature from both traditions were quoted to support my paper, which is to compare the principal understanding of the Divine Unity in both philosophical movements. The concept of the Divine Unity plays a crucial role for both traditions to phrase their sacred understanding of God and His unity in and beyond nature with special emphasis on dissolution of the self, death, and love by transcending God's manifestation through individual experience. For both traditions the human being lives this individual experience absolutely in nature. Therefore, a romantic view of nature, which symbolizes not only pure beauty but also a hidden treasure for the gnostic knowledge, is excessively essential for a spiritual guide. In this esoteric experience of these two similar traditions the human being seeks a union with the absolute reality. The study of the human being's perception of God and His attributes in nature is employed in Sufism as well as American transcendentalism. This paper explicitly supports that Sufism influenced American transcendentalism with its universal perception of the Divine Unity (wahdat al-wujud). This influence contributed to their positive attitude towards nature.

\section{References}

Ahmad, M. (2014). Whitman and Hafiz: expressions of universal love and tolerance. M. Aminrazavi (Ed.), Sufism and American Literary Masters (pp. 153-162). Albany: State University of New York Press.

Ahmad, M. T. (1998). Revelation, rationality, knowledge and truth. Islamabad: Islam International Publications Ltd.

Aminrazavi, M. (2014). Sufism and American literary masters. Albany: State University of New York Press.

Anadolu-Okur, N. (2014).The enduring allure of Rumi and Sufism in American literature. I. Omidvar, and A. R. Richards (Ed.), Muslims and American Popular Culture (pp. 245-266). Santa Barbara: Praeger. 
Bala Ruma, M. (2012). A study of English Romanticism and Sufism as literary movements. Saarbrücken: LAP LAMBERT Academic Publishing.

Burckhardt, T. (2008). Introduction to sufi doctrine. Bloomington: World Wisdom, Inc.

Chittick, W. C. (2009). Sufi thought and practice. The Oxford Encyclopedia of the Islamic World (pp. 207-216). Oxford: Oxford University Press.

Chittick, W. C. (2000). Sufism. Oxford: Oneworld.

Chittick, W. C. (2005). The sufi doctrine of Rumi. Bloomington: World Wisdom, Inc.

Chittick, W. C. (1989). The sufi path of knowledge: Ibn al-Arabi's metaphysics imagination. Albany: State University of New York Press.

Chittick, W. C. (2004). Wahdat al-wujud. Encyclopedia of Islam and the Muslim World. New York: Thomson Gale.

Ekhtiyar, M. (2014). The chronological development of Emerson's interest in Persian mysticism. M. Aminrazavi (Ed.), Sufism and American Literary Masters (pp. 55-74). Albany: State University of New York Press.

Emerson, R. W. (1968). Poems. New York: Ams Press.

Emerson, R. W. (1968). The poet. Essays: Second Series. New York: Ams Press.

Emerson, R. W. (1968). The over-soul. Essays: First Series. New York: Ams Press.

Furlanetto, E. (2017). Walt Whitman's "sea drift" cluster: the encounter of sufi and American selves at Paumanok. V. Bavaro, G. Fusco, S. Fusco, and D. Izzo (Ed.), Harbors, Flows, and Migrations: The USA in/and the World (pp. 95-110). New Castle upon Tyne: Cambridge Scholars Publishing.

Glassé, C. (2001). Wahdat al-wujud. The Concise Encyclopedia of Islam. London: Stacey International. 
Hodder, A. (2010). Asian influences. S. Harbert-Petrulionis, L. Daasow-Walls, and J. Myerson (Ed.), The Handbook of Transcendentalism (pp. 27-37). Oxford: Oxford University Press.

Ibn al-Arabi, M. (1911). Tarjuman al-ashwaq: a collection of mystical odes. (R. A. Nicholson, Trans.) London: Royal Asiatic Society.

Landau, R. (2008). The philosophy of Ibn 'Arabi. London/New York: Routledge.

LeMaster, J.R., and Jahan, S. (2009). Walt Whitman and the Persian poets. Bethesda: Ibex Publishers.

Loloi, P. (2014). Emerson and aspect of Sa'adi's reception. M. Aminrazavi (Ed.), Sufism and American Literary Masters (pp. 91-116). Albany: State University of New York Press.

Manzari, A. (2012). Nature in American transcendentalism. English Language and Literature Studies 2 (3), pp. 61-68. Doi: 10.5539/ells.v2n3p61.

Nicholson, R. A. (1914). The mystics of Islam. London: G. Bell and Sons Ltd.

Nicholson, R. A. (1969). Studies in Islamic poetry. Cambridge: Cambridge University Press.

Rumi, J. ad-Din (2005). Rumi: the book of love. (Barks, C. Trans.) New York: HarperCollins.

Rumi, J. ad-Din. (1926). The Mathnawi of Jalalu'ddin Rumi. (Nicholson, R. A. Trans.) London: Messrs Luzac \& Co.

Sowder, M. (2005). Whitman's ecstatic union. New York/London: Routledge.

Whitman, W. (1891-92). Leaves of grass. Philadelphia: D. McKay.

Whitman, W., and Cowley, M. (Ed.). (1960). Leave of grass: the first (1855) edition. London: The Viking Press.

Whitman, W. (1942). The selected poems of Walt Whitman. New York: Walter J. Black. 